\title{
Streaming Mechanicals and the War on Spotify
}

\author{
Don Gorder \\ Berklee College of Music \\ This paper was presented at the 2019 International Summit of the \\ Music \& Entertainment Industry Educators Association
}

March 21-23, 2019

$\underline{\text { https://doi.org/10.25101/19.20 }}$

\section{Abstract}

The royalties generated from the mechanical reproduction of songs have historically been a major source of income for songwriters. As the consumption of recorded music has moved from physical and downloaded copies to digital streams, songwriters have suffered a major decline in their ability to earn a living from their art and craft. There are two reasons for this: 1) Under copyright law, interactive streaming services (such as Spotify) must obtain a mechanical license to stream the songs, and must pay royalties to the rights holders (typically publishers who then pay the songwriters their share) at rates that are set by law. With perstream rates averaging in fractions of pennies, the mechanical income of songwriters has shriveled. 2) Independent publishers and self-published songwriters have complained loudly that they are not being paid these royalties properly, or at all, by the services, and the services counter that they often don't know whom to pay, due to the lack of data at their disposal that allows them to match the recording with the publishers and songwriters.

A number of prominent members of the publisher/songwriter community chose not to accept this argument, and availed themselves of the legal system to rectify their disputes with Spotify, whom they identified as the primary culprit in the non-payment of mechanical royalties. The National Music Publishers Association also stepped into the fracas, with an attempt to negotiate a settlement with Spotify for unpaid royalties for their members. As this activity gained the attention of the media, it became an impetus for the introduction and ultimate enactment of the Music Modernization Act (MMA) that, it is hoped, will fix these problems.

This presentation will trace the chronology of these disputes - their origin, rationale, and resolution-and how they likely played a role in the ratification of the MMA. Particular attention will be given to an assessment of those elements of the MMA that were designed to fix the problems that spawned the disputes.

Keywords: Music Modernization Act, mechanical royalties, mechanical license, streaming music, Spotify
Don Gorder, Chair and founder of the Music Business/ Management Department at Berklee College of Music, is an attorney, educator, and musician. He holds advanced degrees in law and music (B.M. University of Nebraska, M.M. University of Miami, J.D. University of Denver), has authored numerous articles on the music industry, and has spoken at many national and international music industry events and academic conferences. He co-authored the course Legal Aspects of the Music Industry for Berklee Online. As an attorney, he has represented clients in matters of copyright and contracts, and he remains active as a trumpet player in a variety of jazz and commercial settings. Gorder is Past President of the NAMM-Affiliated Music Business Institutions, a past officer and board member of the Music and Entertainment Industry Educators Association, a past Trustee with the Arts \& Business Council of Greater Boston, and currently serves on the Alumni Advisory Council of the Sturm College of Law, University of Denver. He served for fourteen years with the International Association for Jazz Education as the Resource Team representative for music business/management.

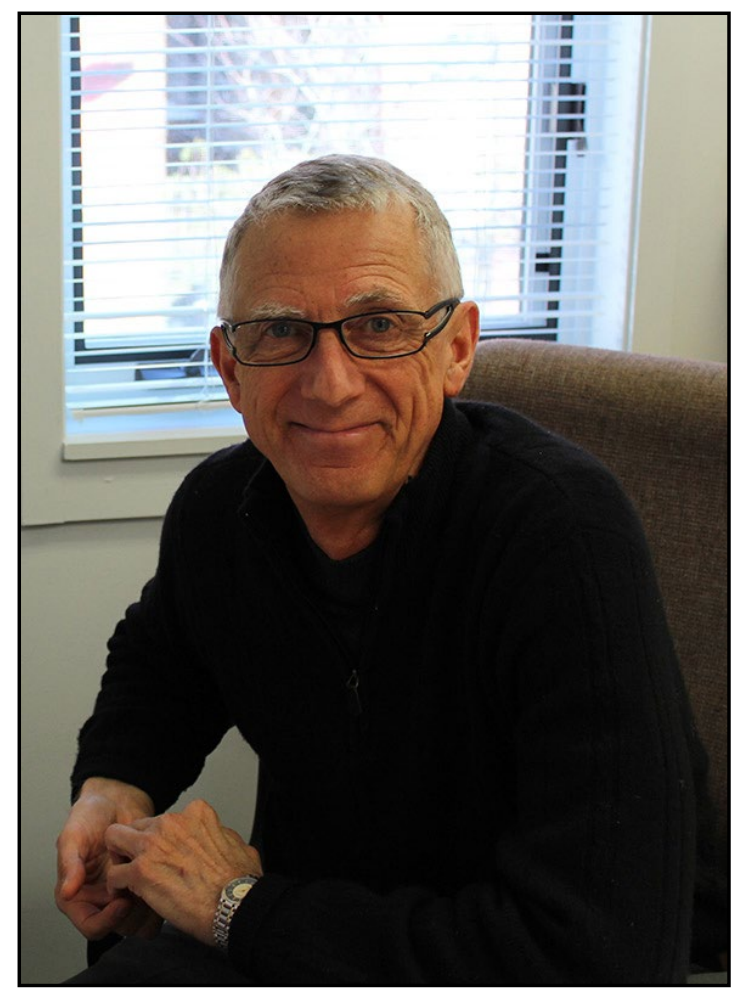




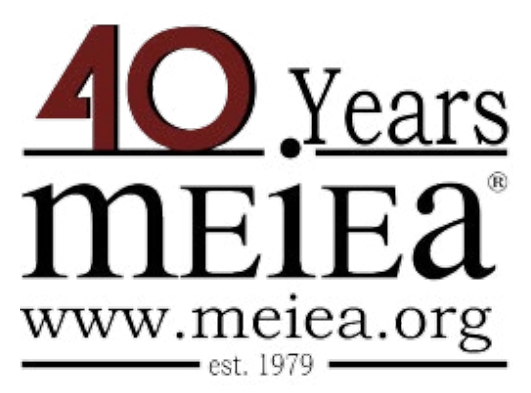

\section{PROCEEDINGS OF THE \\ 2019 INTERNATIONAL SUMMIT \\ OF THE \\ MUSIC \& ENTERTAINMENT \\ INDUSTRY EDUCATORS \\ ASSOCIATION}

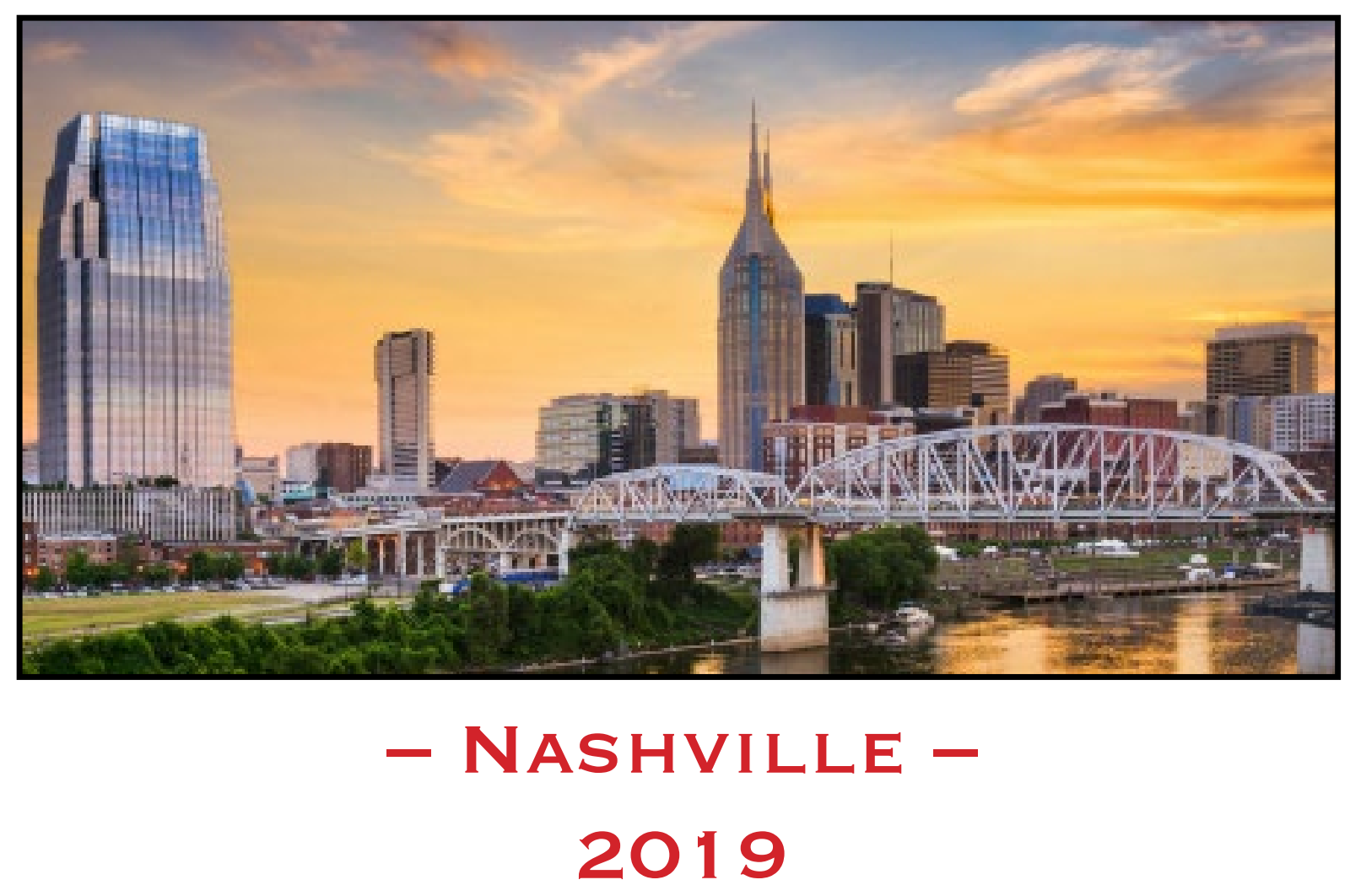

March 21 - 23, $2019 \cdot$ Belmont University - Nashville 